Article

\title{
Spatial Variation of Land Use/Cover Composition and Impact on Surface Urban Heat Island in a Tropical Sub-Saharan City of Accra, Ghana
}

\author{
Darshana Athukorala ${ }^{1, *(D)}$ and Yuji Murayama ${ }^{2}$ (D) \\ 1 Graduate School of Life and Environmental Sciences, University of Tsukuba, 1-1-1, Tennodai, Tsukuba, \\ Ibaraki 305-8572, Japan \\ 2 Faculty of Life and Environmental Sciences, University of Tsukuba, 1-1-1, Tennodai, Tsukuba, Ibaraki \\ 305-8572, Japan; mura@geoenv.tsukuba.ac.jp \\ * Correspondence: s1830207@s.tsukuba.ac.jp or darshana12594@gmail.com
}

Received: 28 August 2020; Accepted: 22 September 2020; Published: 25 September 2020

\begin{abstract}
Rapid urbanization is one of the most crucial issues in the world of the 21st century. Notably, the urban heat island phenomenon is becoming more prominent in megacities and their hinterlands in temperate and subtropical climatic regions. In the daytime in summer, there exists a high possibility of accelerating the land surface temperature (LST) in desert cities, due to the alterations made by human beings in the natural environment. In this study, we investigate the spatial formation of LST in a tropical sub-Saharan city of Accra, a gateway to West Africa, using Landsat data in 2003 and 2017. Machine learning techniques and the different spatial and statistical methods such as tasseled cap transformation (TCT), urban-rural gradient, and multiresolution grid-based and landscape metrics were employed to examine procured land use/cover (LUC) and LST maps. LUC was classified into five categories: Built up, Green 1, Green 2, Bare land, and Water. The results of the analysis indicate that Built up, Green 2, and Bare land had caused the highest heating effect while Green 1 and Water had caused the considerable cooling effect during the daytime in Accra. The urban-rural difference in LST recorded $1.4{ }^{\circ} \mathrm{C}$ in 2003 and $0.28{ }^{\circ} \mathrm{C}$ in 2017. The mean size, mean shape, largest patch, and aggregation of Built up, Green 1, and Green 2 had a strong relationship with the mean LST. It is essential for urban planners to carefully examine the formation and effect of the urban heat island (UHI) for sustainable urban development and landscape policy toward mitigation and adaptation planning in Accra.
\end{abstract}

Keywords: urban heat island; land surface temperature; Accra; urban landscape pattern; tasseled cap transformation; sustainable cities

\section{Introduction}

Urbanization is one of the most fundamental worldwide phenomena in this century. Rapid urbanization has caused socio-economic advancement, including urban infrastructure development, improvement of the transport system, health care, etc. [1,2]. However, urbanization in developing countries has brought various socio-ecological problems, such as deforestation [3,4], overuse of energy $[5,6]$, environmental degradation [7,8], air pollution [9], unhealth, and urban heat island (UHI) $[10,11]$.

The UHI phenomenon results from the relative rise of land surface temperature in the urban areas compared to the surrounding rural environs [11-13]. There are two different concepts, namely, atmospheric UHI and surface UHI. Canopy layer UHI and boundary layer UHI are measured to calculate atmospheric UHI, while land surface temperature (LST) is used to determine surface 
UHI $[11,13]$. Weather station data capture atmospheric UHI, and LST is measured by thermal inferred remote sensing data (TIR) [14].

The LST can be classified into two terms, namely, day and night. Due to the radiation of the sun, the daytime LST is stronger than the nighttime LST. By the change in the intensity of the sun's radiation and the seasons (summer/winter), the magnitude of the UHI varies greatly. The degree of surface UHI can differ due to seasons, regions, solar intensity, land cover, and weather. The variation in these conditions and the magnitude of surface UHIs are most prominent in summer. The size and location of cities are crucial factors in examining the generation of UHI. When the city size increases, the effect of the UHI is also increased [11]. Land-use changes in urban areas, especially the transformation of green areas into built up land, can raise the UHI effect. Anthropogenic processes help this situation get worse.

The UHI phenomenon has multidisciplinary values owing to its broad significance. The topic is popular in academic fields such as; urban ecology, urban geography, urban climatology, and urban planning [11]. The availability of high-quality satellite remote sensing data has promoted the development of UHI studies in recent years [15-17].

For the last two decades, the improvement of remote sensing technologies and GIScience has produced vital information and tools to investigate land use/cover (LUC) patterns and behavior of LST in urban environs $[18,19]$. Many scholars have employed urban-rural gradient analysis, multiresolution analysis in different scales, i.e., mesoscale, local scale, and microscale $[11,18,20]$. Indeed, mitigation of the UHI effect in urban environs can be healthier and more comfortable for people's daily life. Urbanization generates different heating levels between built up and green areas [20,21]. In general, impervious surface covers solar heat-absorbing substances such as concrete asphalt, rock, and gravel. Conversely, tree covers can create an urban cool island condition by the evapotranspiration. The process of evapotranspiration absorbs ambient heat and releases water vapor to the atmosphere [13].

The urban heat island phenomenon is becoming prominent in the megacities and the hinterlands of Africa, especially in tropical and subtropical climatic regions. In this study, we attempt to investigate the spatial formation of LST in a tropical sub-Saharan city of Accra. The objectives of this study are to (1) examine the spatial pattern of LST in Accra, (2) explore the heating effect of land cover categories (LCCs), and (3) detect the relationship between LST and LCCs, from the analysis of urban-rural gradient, tasseled cap transformation (TCT), and landscape metrics. Different variables of the landscape help explain the spatial formation of the LST.

\section{Materials and Methods}

\subsection{Study Area}

In Ghana, there are no daylight-saving time clock changes because the country follows Greenwich Mean Time (GMT) all year (GMT + $0=$ GMT). Today, Ghana plays a vital role as the gateway to West Africa, and Accra is acting as the central hub of private sectors, government, industries, and famous tourist destinations in West Africa [17,22]. Accra stretches along the Gulf of Guinea and the Atlantic Ocean (Figure 1) [17,22]. In 1877, Accra was a small town [22]. Since then, Accra has developed as the capital of Ghana. Accra was enrolled as 100 resilient cities projects in 2014, in which the urban areas and the cities in the world converted to be more resilient in the biophysical and socio-economic challenges [22].

Accra shows sub-Saharan climatic conditions of dry subhumid with a short wet season and a long dry season $[17,23]$. It receives an annual average rainfall of about $180 \mathrm{~cm}$ per year. However, the inter-annual variation of rainfall is usually due to the El Nino condition. The average yearly temperature is around $25-30^{\circ} \mathrm{C}$. Two significant winds influence the study area, blowing from two directions. One is a hot and dusty air mass called "harmattan," which comes from the Sahara Desert from November to March [23]. Another hot, humid, and wet monsoon air mass come from the 
Atlantic Ocean from April to September. High temperatures in these, coupled with a long dry season, account for the area to dry totally [17].

Accra is known as the most urbanized area in Ghana with a large piece of Ghana's industrial establishments [22]. Hence, the Accra area undergoes accelerating population growth and expansion of the built up area [24]. The study area stretches $50 \times 50 \mathrm{~km}^{2}$ with a $25 \mathrm{~km}$ radius from the city center in the central business district.

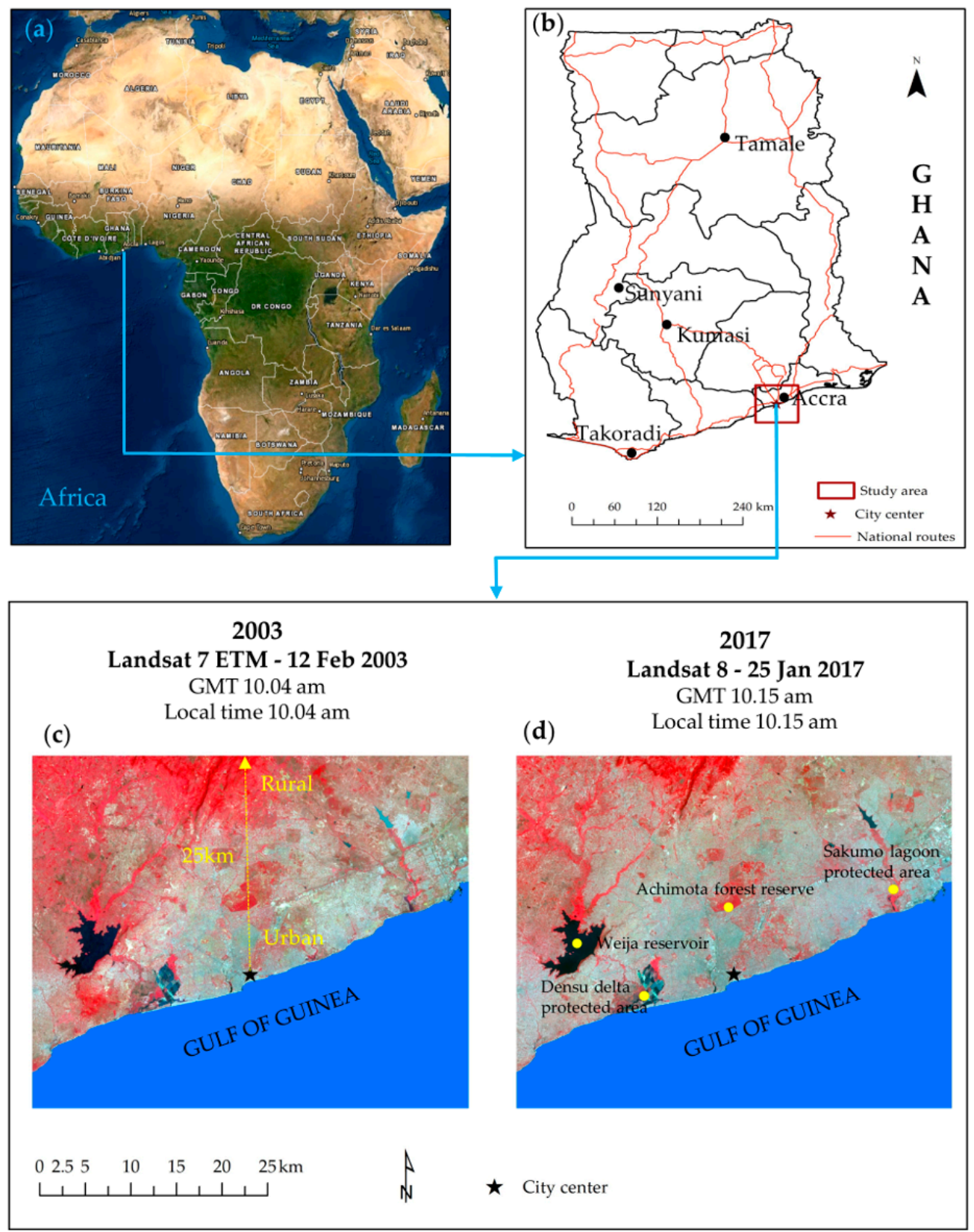

Figure 1. Location of Accra: (a) Ghana and other African countries (Source: Esri ArcGIS online map) [25]; (b) Ghana and the greater Accra area; (c) False color band composite in 2003 (Landsat 7, enhanced thematic mapper-ETM), and (d) False color band composite in 2017 (Landsat 8, operational land imager/thermal infrared sensor-OLI/TIRIS) [26]. Ghana boundary layer was downloaded from DIVA-GIS [27]. 


\subsection{Satellite Data Used and Pre-Processing}

Landsat is the most long-lasting satellite program launched by the National Aeronautics and Space Administration (NASA) and United States Geological Survey (USGS) with a history of more than 48 years, formerly named ERTS (Earth Resources Technology Satellite) [28]. Landsat satellites provide earth surface images for LUC detection. This data has been widely used by LST researchers $[11,29,30]$. Captured Landsat images in 2003 Landsat 7 ETM (12 February; 10: 04 GMT) and Landsat OLI/TRIS 8 (25 January; 10: 15 GMT) in 2017 were employed for our analysis [26]. The pre-processing was conducted before the retrieval of LST. Atmospheric correction and radiometric calibration through the conversion of digital number values were taken from the satellite data: (1) multispectral bands' value of surface reflectance and (2) thermal bands' value of satellite brightness temperature. $L_{\lambda}$ was derived for Landsat 7 ETM and Landsat 8 OLI/TRIS from the quantized calibrated pixel value using Equations (1) and (2).

(a) Regarding Landsat 7 ETM:

$$
L_{\lambda}=\left[\frac{L M A X_{\lambda}-L M I N_{\lambda}}{Q_{c a l ~ m a x}-Q_{c a l ~ m i n}}\right]\left(Q_{c a l}-Q_{c a l ~ m i n}\right)+L M I N_{\lambda}
$$

where, $L_{\lambda}=$ the at-sensor spectral radiance $\left(\mathrm{W} /\left(\mathrm{m}^{2} \mathrm{sr} \mu \mathrm{m}\right)\right), L M A X_{\lambda}=$ spectral at-sensor radiance corresponding to $Q_{\text {cal max }}$ (digital numbers $\left.(\mathrm{DN})=255\right) ; L M I N_{\lambda}=$ spectral at-sensor radiance correspondence to $Q_{c a l \text { min }}\left(\mathrm{W} /\left(\mathrm{m}^{2} \mathrm{sr} \mu \mathrm{m}\right)\right) ; Q_{c a l \text { max }}=255 ; Q_{c a l \text { min }}=1$; and $Q_{c a l}=$ the calibrated pixel value (DN) [31].

(b) Regarding Landsat 8 OLI/TRIS:

$$
L_{\lambda}=M_{L} * Q_{c a l}+A_{L}
$$

where, $L_{\lambda}=$ the at-sensor spectral radiance $\left(\mathrm{W} /\left(\mathrm{m}^{2} \mathrm{sr} \mu \mathrm{m}\right)\right) ; M_{L}=$ scale factor multiplication of metadata; $A_{L}=$ scale factor of radiance for the metadata; and $Q_{c a l}=\mathrm{DN}$ pixel value [29].

The brightness temperature was calculated using Equation (3). (The DN values of the thermal bands of Landsat ETM, Landsat-8 OLI/TIRS were transformed).

$$
T_{b}=\frac{K_{2}}{\operatorname{In}\left[\frac{K_{1}}{L_{\lambda}}+1\right]}
$$

where, $T_{b}=$ brightness temperature of the top of atmosphere (TOA); in Kelvin; $K_{1}, K_{2}=$ calibration constants in the Landsat 7 ETM and Landsat 8 OLI/TRIS; In and $L_{\lambda}=$ per-launch logarithm and the spectral radiance $\left(\mathrm{W} /\left(\mathrm{m}^{2}{ }^{*} \mathrm{sr}^{*} \mu \mathrm{m}\right)\right)$, respectively $[32,33]$.

Then, the standard method of Dark Object Reduction (DOS) was applied to the Landsat 7 ETM and Landsat 8 OLI/TRIS using Equations (4) and (5).

(a) Regarding Landsat 7 ETM:

$$
\rho_{\lambda}=\frac{\pi * L_{\lambda} * d^{2}}{\operatorname{ESUN}_{\lambda} * \cos \theta_{s}}
$$

where, $\rho_{\lambda}=$ TOA reflectance; $d=$ distance of the Earth and Sun (astronomical units); $\pi=$ constant (3.14159); $L_{\lambda}=$ the at-sensor spectral radiance $\left(\mathrm{W} /\left(\mathrm{W} /\left(\mathrm{m}^{2} \mathrm{sr} \mu \mathrm{m}\right)\right) ; E S U N_{\lambda}=\right.$ the mean of exo-atmospheric solar irradiance; and $\cos \theta_{s}$ is the angle of solar zenith [32].

(b) Regarding Landsat 8 OLI/TRIS:

$$
\rho_{\lambda}=\frac{M_{\rho} * Q_{c a l}+A_{p}}{\sin \theta}
$$

where, $\rho_{\lambda}=$ the TOA reflectance; $M_{\rho}=$ scale factor multiplication of metadata; $A_{\rho}=$ scale factor of radiance from the metadata; $Q_{c a l}=\mathrm{DN}$ pixel value; and $\sin \theta=$ angle of solar elevation [33]. 


\subsection{Retrieval of LST}

The commonly used method of acquiring unprocessed Landsat data requires the $\mathrm{DN}$ value of thermal bands (Landsat thematic mapper (TM) and ETM = band 6, and Landsat 8 OLI/TIRS = bands 10 and 11) $[11,31,34]$. First, we derived absolute radiance values and conducted the derivation of satellite brightness temperature. We used the pre-processed bands (band 6 for Landsat 7 ETM and bands 10 and 11 of Landsat 8 OLI/TRIS). Subsequently, Kelvin values of the top of atmosphere brightness temperature were transferred to Celsius $\left({ }^{\circ} \mathrm{C}\right)$. The proportion of vegetation and then emissivity corrected LST maps were derived using Equation (6):

$$
L S T=\frac{T_{b}}{1+\left(\lambda \times T_{b} / \rho\right) I N \varepsilon}
$$

where, $T_{b}=$ Landsat 7 ETM band 6, Landsat 8 OLI/TRIS band 10 brightness temperature; $\lambda=$ wavelength of emitted radiance (for band 6, $11.5 \mu \mathrm{m})$; and (10.8 $\mu \mathrm{m}$ for band 10); $\rho=h \times c / \sigma\left(1.438 \times 10^{-2} \mathrm{~m} \mathrm{~K}\right)$; $\sigma=$ Boltzmann constant $\left(1.38 \times 10^{-23} \mathrm{~J} / \mathrm{k}\right) ; \mathrm{h}=$ Planck's constant $\left(6.626 \times 10^{-34} \mathrm{Js}\right) ; \mathrm{c}=$ velocity of light $\left(2.998 \times 10^{8} \mathrm{~m} / \mathrm{s}\right) ; \varepsilon=$ emissivity of the land surface; $I N=$ per-launch logarithm. Finally, the calculated Kelvin values of LST were converted to the degree of the Celsius $\left({ }^{\circ} \mathrm{C}\right)$ [11].

Land surface emissivity $(\varepsilon)$ was calculated using Equation (7):

$$
\varepsilon=m p_{v}+n
$$

where, $m=\left(\varepsilon_{v}-\varepsilon_{S}\right)-\left(1-\varepsilon_{s}\right) \mathrm{F} \varepsilon_{v}$, and $n=\varepsilon_{S}+\left(1-\varepsilon_{s}\right) \mathrm{F} \varepsilon_{v}$; where, $\varepsilon_{s}$ and $\varepsilon_{v}$ are the soil emissivity and vegetation emissivity; $\mathrm{F}$ is a form factor, the mean value of which assumes that various geometrical distributions is 0.55 , respectively [34].

$P_{v}$, the vegetation proportion, was derived using Equation (8):

$$
P_{v}=\frac{N D V I-N D V I_{\min }}{N D V I_{\max }-N D V I_{\min }}
$$

where, $N D V I$ is the Normalized Difference Vegetation Index; the $N D V I_{\min }$ and $N D V I_{\max }=$ the minimum value of NDVI and the maximum value of the NDVI, respectively [35].

NDVI was derived using Equation (9):

$$
N D V I=\frac{\rho N I R-\rho R E D}{\rho N I R+\rho R E D}
$$

where, NDVI was derived using the surface reflectance of Landsat 7 ETM band $3(\rho R E D)$ and band 4 (near-infrared $(\rho N I R))$, Landsat 8 OLI/TRIS band $4(\rho R E D)$, and band $5(\rho N I R)$ [11].

\subsection{LUC Classifications}

The LUC of the study area was classified using three machine learning methods facilitating $\mathrm{R}$ software: K-nearest neighbor, support vector machines, and random forest [36]. We employed supervised learning for the classification. Five types of LCCs were considered in this classification, including, (i) Built up (consists of the impervious surface such as buildings, roads, airports, schools, and industrialized areas.); (ii) Green 1 (consists of forest areas, woodland, mangrove, and bushland with big tree crowns); (iii) Green 2 (includes grassland, and cropland scattered green space); (iv) Bare land (includes exposure areas without any natural and human-made areas); and (v) Water (consists of rivers, lake reservoirs, lagoon, and wetlands). We applied a random sampling method to cover all LUC categories in the study area and produced 400 points each year. Google Earth's historical images were utilized as reference data for accuracy assessment. Then, we made three LUC maps for each year, based on five LCCs. 
We ranked the classified LUC maps based on the highest value of overall accuracy and made the LUC maps generated by K-nearest neighbor (overall accuracy was over $88 \%$ each year). Afterward, we conducted the post-classification corrections as the majority filter and hybrid classification method to avoid misclassification errors and salt and pepper noises [37-39].

\subsection{Tasseled Cap Transformation (TCT)}

Only LUC classification is not enough to understand the spatial formation of LST in Accra. Therefore, we use TCT in this study because TCT gives useful information on brightness, greenness, and wetness in Accra. Using the TCT concept, which was first introduced by Kauth, R.J. and Thomas G.S. [40], we can measure ecological footprints and urban development with high-resolution multispectral sensors (multispectral scanner system (MSS), Landsat TM, ETM+, Landsat OLI/TIRS, and Quick bird). The first component is brightness (orthogonal to the brightness), which is comprised of bare soil and cover up to some extent, built up areas, and natural environments such as asphalt, rock, gravel, and other bare places. Greenness, the second component, is related to healthy vegetation. The third is wetness, being orthogonal to brightness and greenness. The wetness category is associated with hydro-related features such as soil moisture, water, and wet elements. Brightness, wetness, and greenness of the TCT consist of $97 \%$ important information of the image. The Brightness Index (BI), Greenness Index (GI), and Wetness Index (WI) of Landsat 7 ETM and Landsat 8 OLI/TRIS are derived using Tables 1 and 2. Finally, the TCT components of BI, GI, and WI are rescaled to 1-100 using a rescale function tool available in ArcGIS 10.6.

Table 1. Tasseled cap transformation (TCT) for Landsat 7 ETM [41].

\begin{tabular}{cccccccc}
\hline Index & Band 1 & Band 2 & Band 3 & Band 4 & Band 5 & Band 6 & Equation No. \\
\hline BI & 0.3037 & 0.2793 & 0.4743 & 0.5585 & 0.5082 & 0.1863 & 10 \\
\hline GI & -0.2848 & -0.2435 & -0.5436 & 0.7243 & 0.0840 & -0.1800 & 11 \\
\hline WI & 0.1509 & 0.1973 & 0.3279 & 0.3406 & -0.7112 & -0.4572 & 12 \\
\hline
\end{tabular}

Table 2. TCT for Landsat 8 OLI/TRIS [42].

\begin{tabular}{cccccccc}
\hline Index & Band 2 & Band 3 & Band 4 & Band 5 & Band 6 & Band 7 & Equation No. \\
\hline BI & 0.3029 & 0.2786 & 0.4733 & 0.5599 & 0.508 & 0.1872 & 13 \\
\hline GI & -0.2941 & -0.243 & -0.5424 & 0.7276 & 0.0713 & -0.1608 & 14 \\
\hline WI & 0.1511 & 0.1973 & 0.3283 & 0.3407 & -0.7117 & -0.4559 & 15 \\
\hline
\end{tabular}

Note: BI is Brightness Index, GI is Greenness Index, and WI is Wetness Index.

\subsection{Spatial Analysis of Accra}

Many studies related to the UHI have examined the usefulness of the satellite remote sensing data to explore the relationship between landscape pattern and LST [30,43-49]. Recently, urban-rural gradient analysis, multiresolution grid-based analysis, and landscape configuration analysis have been conducted in UHI studies. Each technique gives some insights into a better understanding of the UHI in the study area, which provides useful information for urban designers and urban planners to mitigate the UHI effect. In the spatial analysis, we conducted three methods, i.e., urban-rural gradient analysis, multiresolution grid-based analysis, and landscape metrics-based analysis. We excluded water and bare land categories from this section because (i) we already calculated the WI in the study area in Section 2.5, and (ii) bare land showed a very low amount compared to the other LCCs in the study area. 


\subsubsection{Urban-rural Gradient Analysis}

We examined spatial differences between LST and LCCs along the urban-rural gradient. First, we prepared the multiple ring buffer zones from the city center, and 50 ring buffer zones were created based on a $500 \mathrm{~m}$ distance interval. Second, we extracted the mean LST and the density of LCCs. The same 50 ring buffer zones were applied to extract TCT of the study area.

\subsubsection{Multiresolution Grid-Based Analysis}

This analysis enables us to explore the LCCs' influence on the mean LST using polygon grids. The statistical relationship between LCCs and mean LST was calculated to identify the impact of LCC ' on the mean LST. However, a suitable grid size is not yet identified in the literature, and they are still discussing what the proper grid size is. Myint et al. (2010) [50] found that an appropriate grid size is between $210 \mathrm{~m} \times 210 \mathrm{~m}$ and $270 \mathrm{~m} \times 270 \mathrm{~m}$. Estoque et al. (2017) [11] revealed that the right grid size is between $210 \mathrm{~m} \times 210 \mathrm{~m}$ and $240 \mathrm{~m} \times 240 \mathrm{~m}$ in the investigation of three Southeast Asian megacities; Bangkok, Jakarta, and Manila. Hou et al. (2020) [51] used $210 \mathrm{~m} \times 210 \mathrm{~m}, 450 \mathrm{~m} \times 450 \mathrm{~m}$, and $690 \mathrm{~m} \times$ $690 \mathrm{~m}$ to investigate the relationship between the land cover category and the mean LST in Hangzhou. In this research, we used different sizes of polygon grids, i.e., $90 \mathrm{~m} \times 90 \mathrm{~m}, 120 \mathrm{~m} \times 120 \mathrm{~m}, 150 \mathrm{~m} \times$ $150 \mathrm{~m}, 180 \mathrm{~m} \times 180 \mathrm{~m}, 210 \mathrm{~m} \times 210 \mathrm{~m}, 240 \mathrm{~m} \times 240 \mathrm{~m}, 270 \mathrm{~m} \times 270 \mathrm{~m}, 300 \mathrm{~m} \times 300 \mathrm{~m}$, and $330 \mathrm{~m} \times$ $330 \mathrm{~m}$. After creating these polygon grids, we measured the mean LST and the density of LCCs in Accra. The set of multiresolution polygon grids was used to examine the TCT's influence on the mean LST of the study area. An attempt was made to investigate the most suitable grid size to simulate and predict meteorological and physical attributes using statistical nexus between atmospheric and surface temperature and LCCs in Accra.

\subsubsection{Landscape Metrics-Based Analysis}

This analysis enables us to examine the spatial traits of patches of LCCs influencing on the LST. Based on FRAGSTATS v4.2 software, we calculated the mean patch area of LCCs. We got Built up of 3.94 ha and 7.49 ha, Green 1 of 2.59 ha and 2.48 ha, Green 2 of 3.92 ha, and 3.39 ha in 2003 and 2017, respectively. Considering these results, multiresolution polygon grids analysis in Section 2.6.2 was not suitable for landscape metrics-based analysis. Based on previous studies [11,51-53], we created a $3 \mathrm{~km}$ $\times 3 \mathrm{~km}$ fishnet to divide the study area. Forty out of 116 polygon grids were selected randomly for further investigation. We examined the four-landscape metrics, namely, mean patch area (AREA_MN), mean shape index (SHAPE_MN), largest patch index (LPI), and aggregation index (AI) (Table 3) by employing FRAGSTATS v4.2 software. The analytical parameter was 8-cell neighborhood in 2003 and 2017, respectively. Bivariate correlation analysis was applied to determine the statistical relationships between LCCs and mean LST in $3 \mathrm{~km} \times 3 \mathrm{~km}$ grid size.

Table 3. Four spatial metrics used in this analysis [54].

\begin{tabular}{llll}
\hline \multicolumn{1}{c}{ Spatial metrics } & \multicolumn{1}{c}{ Formula } & \multicolumn{1}{c}{ Description } & Units \\
$\begin{array}{l}\text { Mean Patch Area } \\
\text { (AREA_MN) }\end{array}$ & AREA_MN $(\mathrm{ha})=\frac{1}{10,000 \times \mathrm{n}} \times \sum_{\mathrm{i}=1}^{\mathrm{n}} \mathrm{x}_{\mathrm{i}}$ & $\begin{array}{l}\text { The spatial distribution and } \\
\text { heterogeneity of the area; } \\
\text { Area_MN calculates the } \\
\text { patch area. }\end{array}$ & ha \\
\hline $\begin{array}{l}\text { Mean Shape Index } \\
\text { (SHAPE_MN) }\end{array}$ & SHAPE_MN $=\frac{1}{\mathrm{n}} \times \frac{0.25 \mathrm{p}_{\mathrm{i}}}{\sqrt{\mathrm{x}_{\mathrm{i}}}}$ & $\begin{array}{l}\text { Identify the shape complexity } \\
\text { involving the LCCs. }\end{array}$ & $\geq 1$ \\
\hline Largest Patch Index $(\mathrm{LPI})$ & $\mathrm{LPI}=\frac{\mathrm{max}_{\mathrm{ai}}}{\mathrm{a}}(100)$ & $\begin{array}{l}\text { LPI helps to identify the } \\
\text { advantages of the LCCs. }\end{array}$ & $0-100$ \\
\hline Aggregation Index $(\mathrm{AI})$ & $\mathrm{AI}(\%)=\left(\frac{\mathrm{g}_{\mathrm{i}}}{\mathrm{max}_{\mathrm{gi}}}\right) \times(100)$ & $\begin{array}{l}\text { Measure class types aggregation } \\
\text { levels in the area. }\end{array}$ & percentage \\
\hline
\end{tabular}




\section{Results}

\subsection{Spatio-Temporal Change of LUC and LST (from 2003 to 2017)}

The LUC maps show that Accra experienced rapid urbanization from 2003 to 2017 (Figure 2). Built up increased from $30.51 \%$ to $51.90 \%$, and Green 1 decreased from $22.45 \%$ to $11.26 \%$ during the study period. Green 2 decreased from $46.71 \%$ to $32.49 \%$. Overall, the rapid expansion of Built up has led to changes in the landscape pattern in the study area. It can be identified that the spatial dispersion of land cover categories (Figure 2) determines the spatial variation of the land surface temperature of Accra (Figure 3).

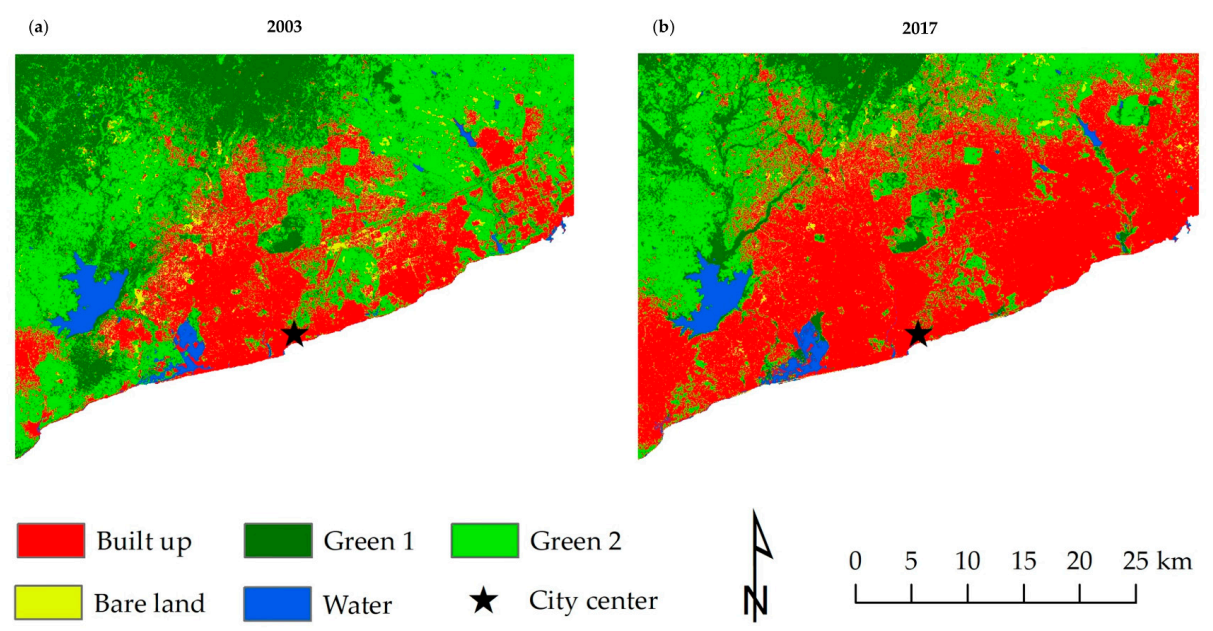

Figure 2. Land use/cover (LUC) maps of Accra: (a) 2003 LUC map; and (b) 2017 LUC map.

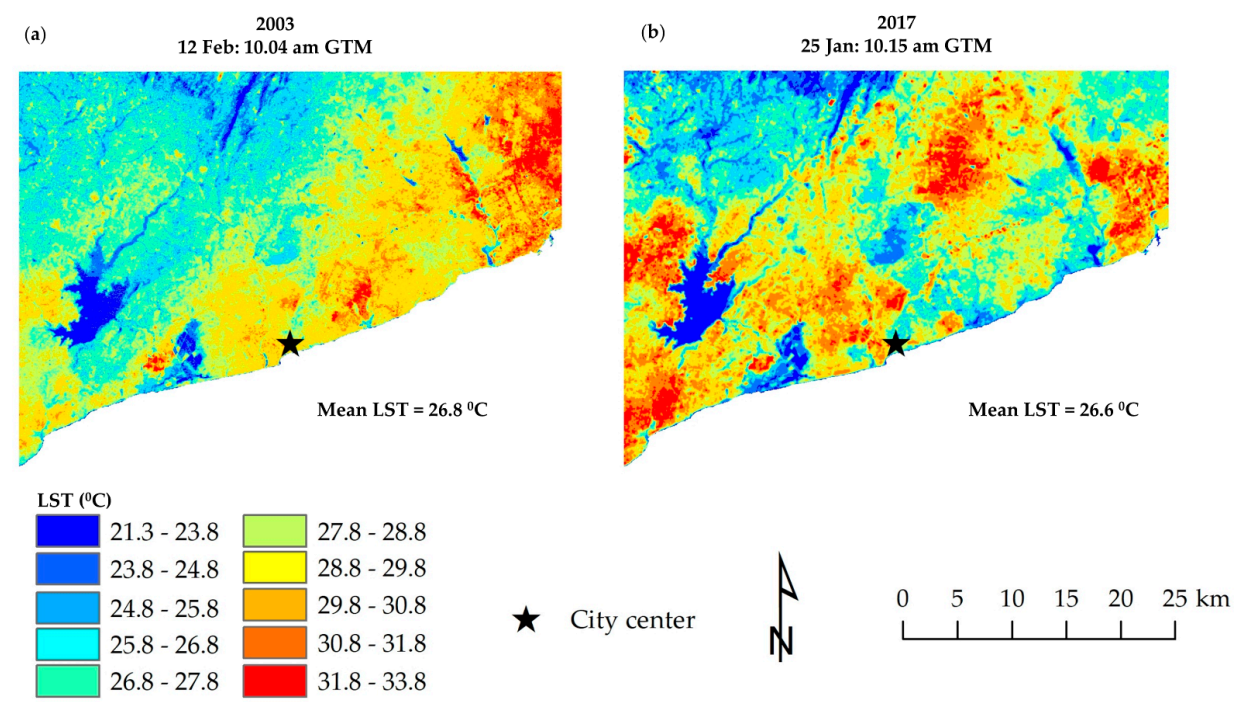

Figure 3. Land surface temperature (LST) maps of Accra: (a) 2003 LST map; and (b) 2017 LST map.

The LST maps of Accra for 2003 and 2017 are shown in Figure 3. On 12 February 2003, 10.04 GMT, the LST in the study area was recorded from $21.30^{\circ} \mathrm{C}$ to $33.61^{\circ} \mathrm{C}$ with the mean LST of $26.87^{\circ} \mathrm{C}$. On 25 January 2017, 10:15 GMT; the LST was recorded from $21.67^{\circ} \mathrm{C}$ to $31.55^{\circ} \mathrm{C}$ with the mean LST of $26.62^{\circ} \mathrm{C}$. In 2003, the clusters with high LST were mostly concentrated on the eastern and southern parts. In 2017, the clusters with high LST were widely distributed in the study area. Especially, Built up $\left(27.09{ }^{\circ} \mathrm{C}\right.$ in 2003 and $27.50^{\circ} \mathrm{C}$ in 2017), Green $2\left(26.66^{\circ} \mathrm{C}\right.$ in 2003 and $27.28^{\circ} \mathrm{C}$ in 2017), and Bare land $\left(26.96^{\circ} \mathrm{C}\right.$ in 2003 and $27.35^{\circ} \mathrm{C}$ in 2017$)$ had the most substantial heating effect while Green $1\left(25.07^{\circ} \mathrm{C}\right.$ 
in 2003 and $25.58^{\circ} \mathrm{C}$ in 2017) and Water $\left(23.57^{\circ} \mathrm{C}\right.$ in 2003 and $23.87^{\circ} \mathrm{C}$ in 2017) had a cooling effect during the daytime in Accra (Figure 4).

(a)

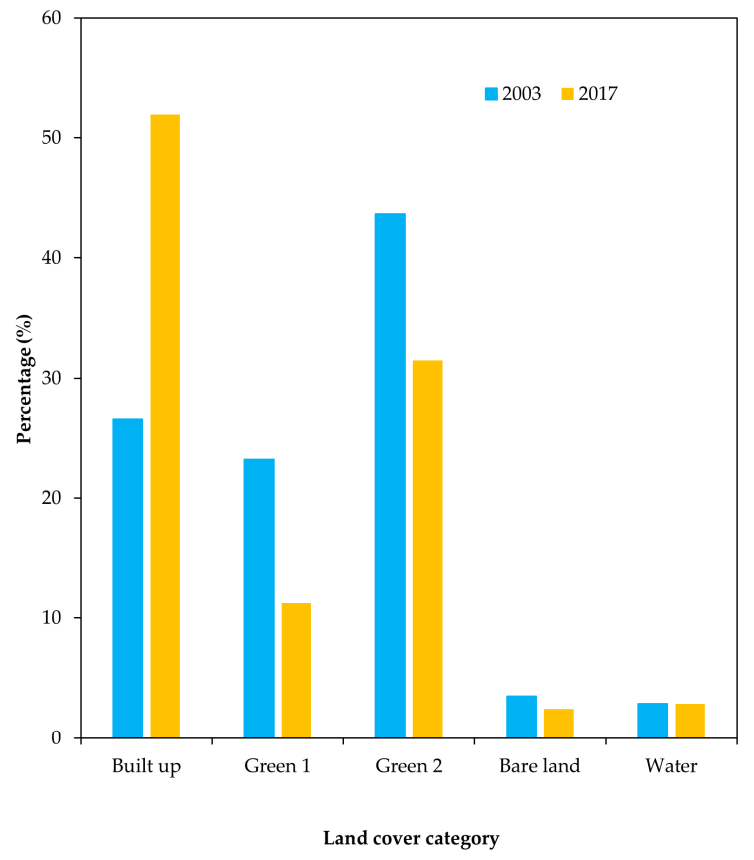

(b)

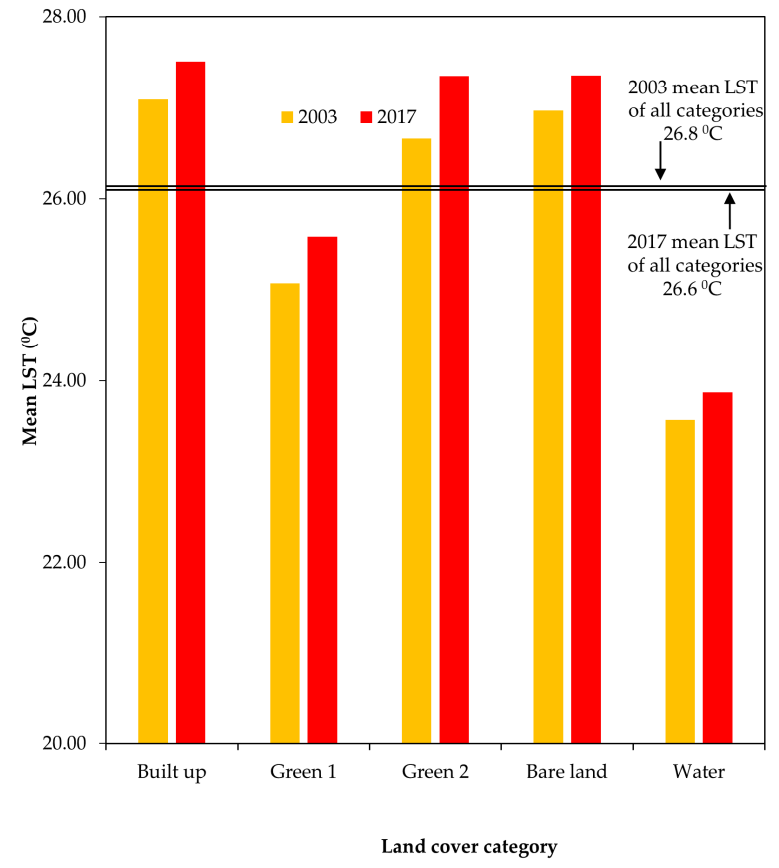

Figure 4. (a) Percentage of land cover categories (LCCs) and (b) mean LST of LCCs.

\subsection{TCT; LCCs vs. LST}

The TCT maps and the result of correlation analysis are shown in Figure 5 and Appendix A. In 2003, BI was mostly accumulated in the eastern areas; GI was mainly accumulated in the northeast direction from the city center, and WI was concentrated in the surrounding zones of the city center. However, in 2017, BI was spread out widely (Figure 5), corresponding with the Built up category of the LUC map (Figure 2), and GI did not become more extended. We used 20,000 random sample points to identify the relationship between the density of Built up, Green 1, and Green 2, as well as BI, GI, WI, and mean LST. The results showed a positive correlation $(r=0.451$ in 2003 and $r=0.541$ in 2017) with BI and mean LST and negative correlation $(r=-0.623$ and $r=-0.207$ in 2003 and $r=-0.380$ and $r=-0.689$ in 2017) with GI, WI, and mean LST (Appendix A). All correlation results were significant at the 0.01 level of confidence.

The results indicate that the density of Built up and the mean LST had a consistent trend. The ring zones near the city center had the highest mean LST, which was decreased along the urban-rural gradient both in 2003 and 2017 (Figure 6a). In contrast, the density of Green 1 and Green 2 shows the lowest mean LST closest to the city center. The density increased away from the city center showing the majority of the rural area both in 2003 and 2017 (Figure 6a).

The BI did not have the highest LST in the city center. This trend gradually raised radially, and again fell near the $18 \mathrm{~km}$ zone (Figure $6 \mathrm{~b}$ ). The WI and the mean LST had a consistent pattern, and both fell away from the city center. It is characteristic that WI was dominant in urban areas. However, GI showed the opposite trend along the urban-rural gradient. In 2017, the mean LST was low near the city center and continuously increased until the $5 \mathrm{~km}$ zone along the urban-rural gradient (Figure 6b). 
2003

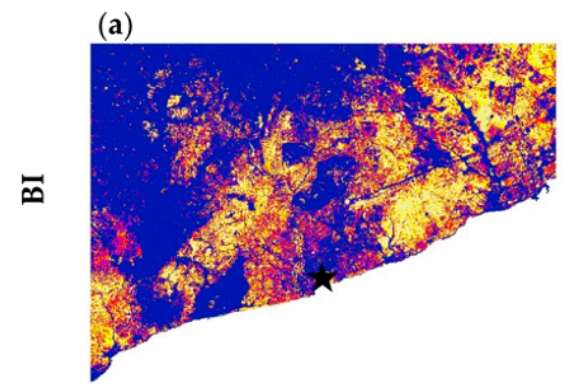

$1-20$

$20-40$

(c)

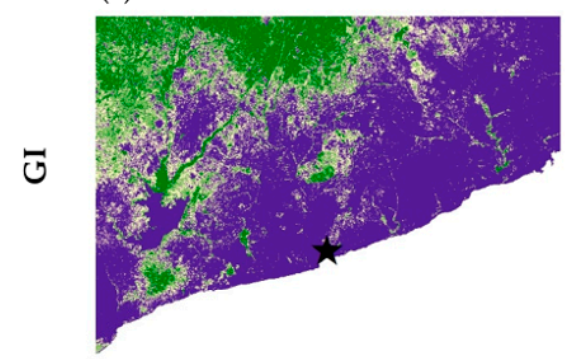

$1-20$
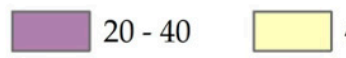

$40-60$
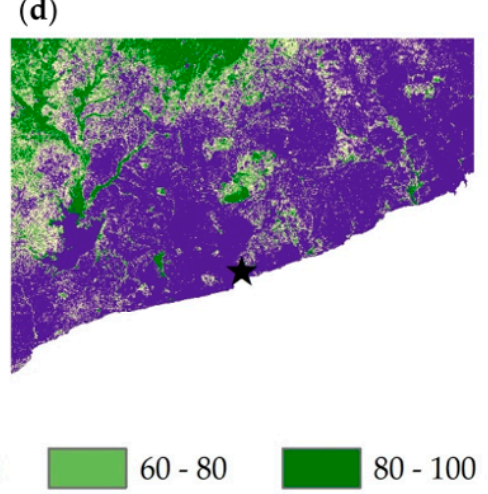

(e)

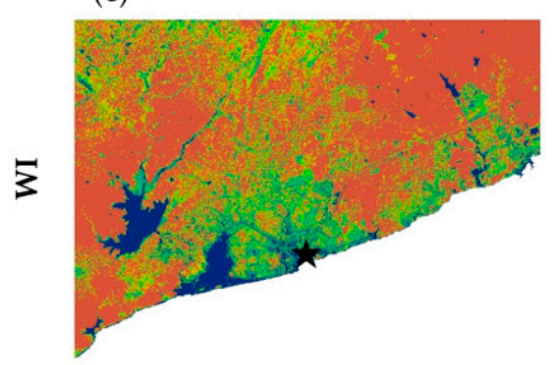

$1-20 \square 20-40$

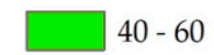

$40-60$

(f)

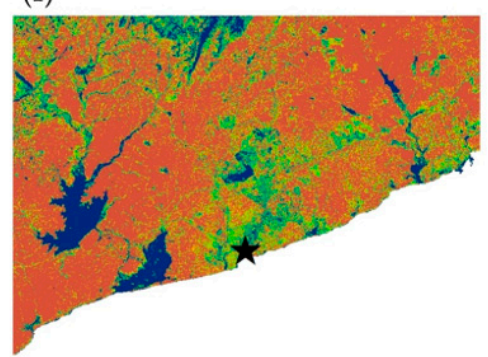

$60-80$

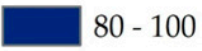

\section{$\star \quad$ City center}

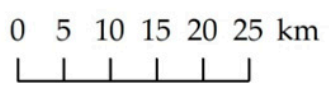

$N$

Figure 5. The TCT results of BI, GI, and WI: (a) BI in 2003; (b) BI in 2017; (c) GI in 2003; (d) GI in 2017; (e) WI in 2003; and (f) WI in 2017.

\subsection{Land Cover Density and TCT vs. Multiresolution Grid-Based Analysis}

Figures 7 and 8 reveal the strong relationship between the density of Built up, Green 1, and Green 2 vs. the mean LST, and TCT vs. the mean LST both in 2003 and 2017. All results were statistically significant at the 0.01 level of confidence, over the multiresolution grid size; i.e., $90 \mathrm{~m} \times 90 \mathrm{~m}, 120 \mathrm{~m} \times$ $120 \mathrm{~m}, 150 \mathrm{~m} \times 150 \mathrm{~m}, 180 \mathrm{~m} \times 180 \mathrm{~m}, 210 \mathrm{~m} \times 210 \mathrm{~m}, 240 \mathrm{~m} \times 240 \mathrm{~m}, 270 \mathrm{~m} \times 270 \mathrm{~m}, 300 \mathrm{~m} \times 300 \mathrm{~m}$, and $330 \mathrm{~m} \times 330 \mathrm{~m}$. Mean LST and Built up and Green 1 in 2003 (Figure 7a) had the inverse (negative) relationship, while in 2017 had a direct (positive) relationship (Figure 7d). 
(a)

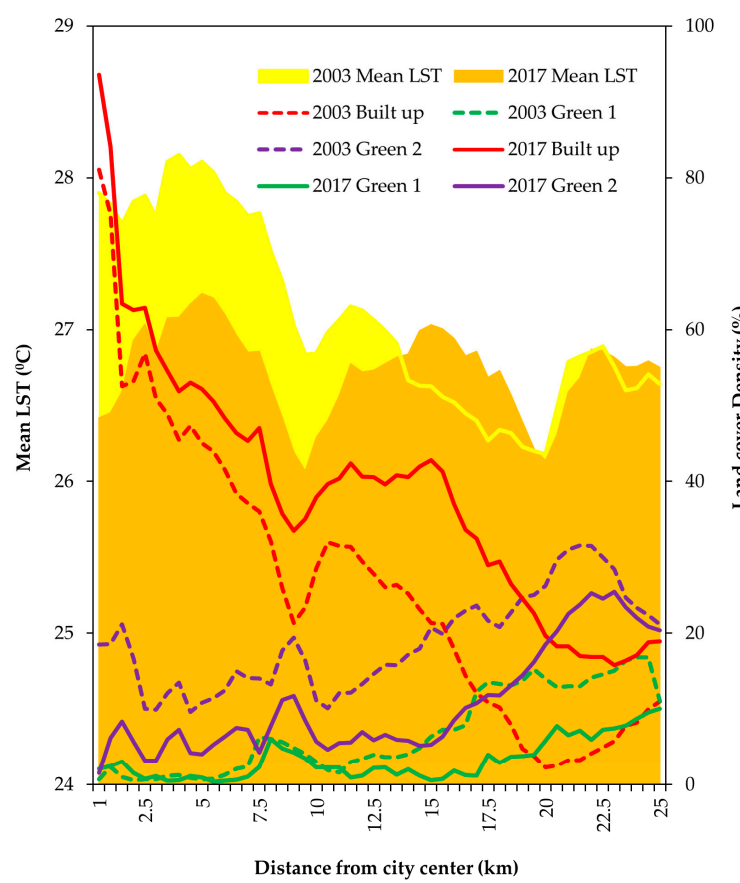

(b)

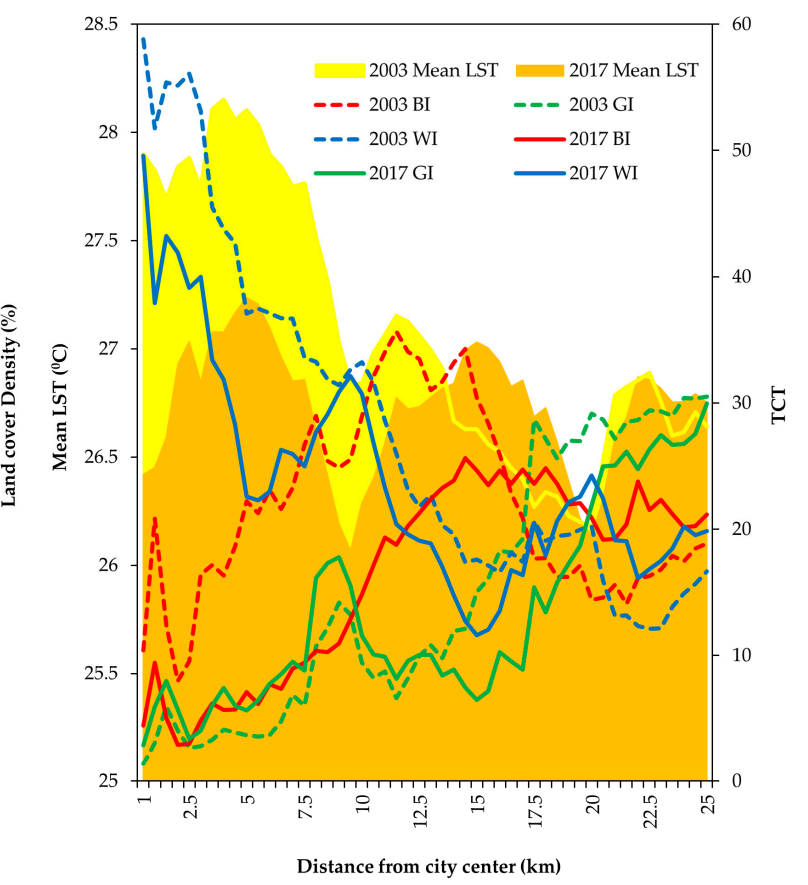

Figure 6. Urban-rural gradient analysis; (a) Mean LST and land cover density; (b) Mean LST and TCT.
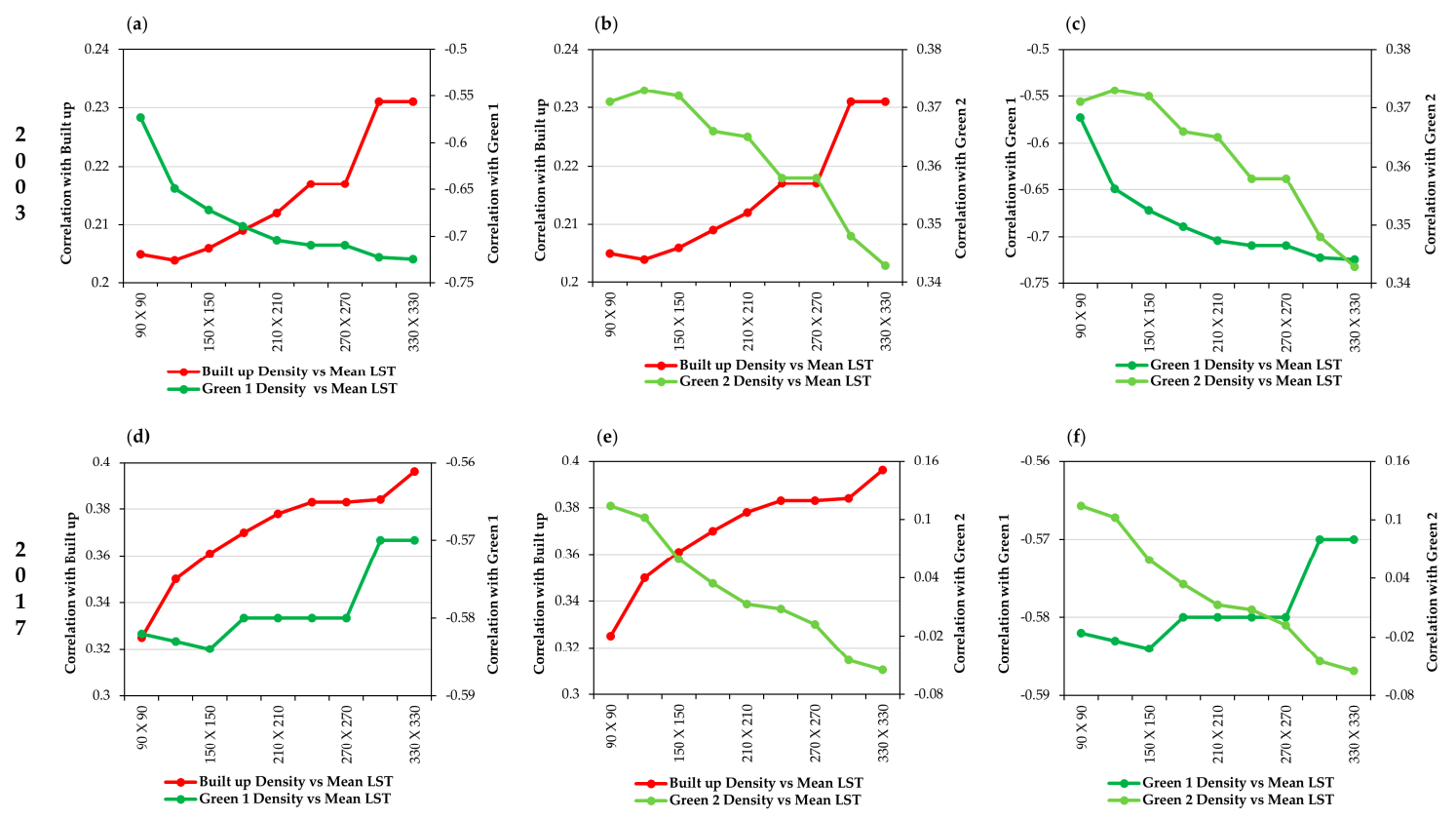

Figure 7. Multiresolution grid-based analysis. The correlation coefficient between Built up, Green 1, Green 2, and mean LST: (a) Built up vs. Green 1 in 2003; (b) Built up vs. Green 2 in 2003; (c) Green 1 vs. Green 2 in 2003; (d) Built up vs. Green 1 in 2017; (e) Built up vs. Green 2 in 2017; and (f) Green 1 vs. Green 2 in 2017. 

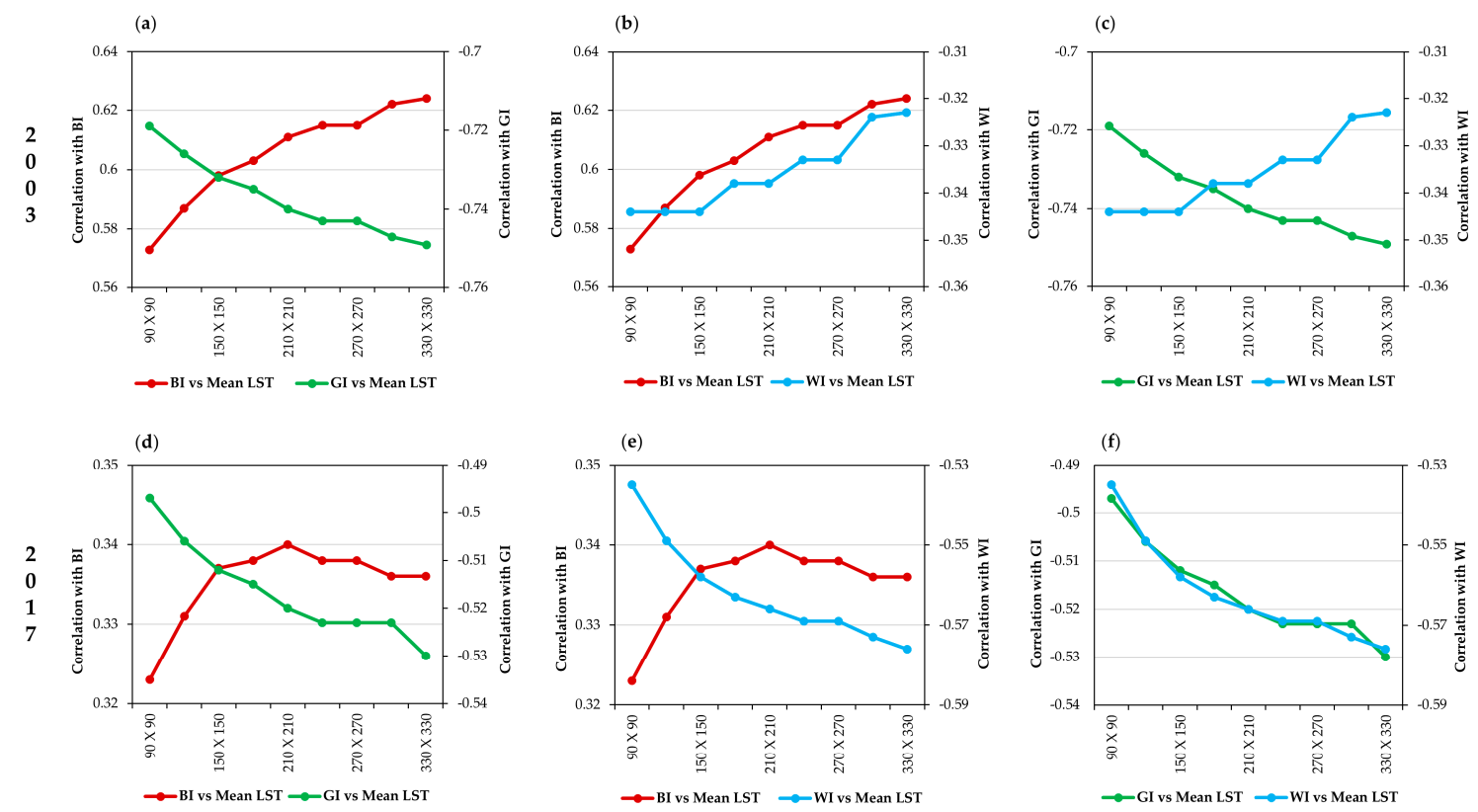

Figure 8. Multiresolution grid-based analysis. The correlation coefficient between BI, GI, WI, and mean LST: (a) BI vs. GI in 2003; (b) BI vs. WI in 2003; (c) GI vs. WI in 2003; (d) BI vs. GI in 2017; (e) BI vs. WI in 2017; (f) GI vs. WI in 2017.

Notably, the density of Built up and the mean LST had a strong relationship when grid size increased both in 2003 and 2017 (Figure 7). However, the decreasing trend the coefficient value between the mean LST and the Green 1 shows that the impact of the Green 1 on the mean LST became stronger when the grid size became smaller. Green 1 has a cooling effect in closer contiguities. It indicates that the coefficient value between the mean LST and Green 1 reduces when the grid size becomes larger. Green 2 and the mean LST coefficient values also decrease when the grid size becomes larger in the two-time points.

Among the grid-based analysis of the TCT, the mean LST and BI had a strong and positive correlation as grid size became larger. Mean LST and GI and WI had a strong negative relationship as grid size became smaller both in 2003 and 2017. In general, BI can retain more solar radiation to enhance the surface temperature. In contrast, GI and WI have a cooling effect of supporting evaporation. These mechanisms explain why the correlation became stronger between BI and the mean LST and WI and the mean LST as grid size increased.

Conversely, the correlation results were decreased between the mean LST and GI as the grid size decreased. BI can make a heating effect in closer vicinities. The trend of coefficient value between the BI and the mean LST increases when the grid size becomes smaller. In contrast, GI can make a cooling environment in closer proximity. This explains that the coefficient value between the mean LST and GI lowers when the grid size becomes larger.

\subsection{Landscape Metrics vs. LST}

The results show that Built up, Green 1, and Green 2 of LCCs have a positive relationship with the LST both in 2003 and 2017 (Table 4). The correlation coefficients of Built up and Green 2 show a positive correlation with mean LST in the study period. In contrast, Green 1 has a negative correlation with the mean LST both in 2003 and 2017. The values of the four metrics of Green 1 indicate a descending trend due to a reduction of Green 1 in Accra. This result matches with the LUC classification results in the study area (Figure 2). The relationships between Green 1 and the mean LST of LPI and AI were from -0.599 and -0.686 in 2003 to -0.249 and -0.272 in 2017. The Area_MN and Shape_MN of Green 1 revealed a significant negative correlation in the study period. The reduction of AI indicates that 
the mean patches of Green 1 were more fragmented between 2003 and 2017, showing the negative influences of powerful aggregating with LST.

Table 4. Correlation coefficients between four spatial metrics and mean LST.

\begin{tabular}{|c|c|c|c|c|c|c|c|c|c|c|c|c|}
\hline & \multicolumn{4}{|c|}{ Built up } & \multicolumn{4}{|c|}{ Green 1} & \multicolumn{4}{|c|}{ Green 2} \\
\hline & \multicolumn{2}{|c|}{2003} & \multicolumn{2}{|c|}{2017} & \multicolumn{2}{|c|}{2003} & \multicolumn{2}{|c|}{2017} & \multicolumn{2}{|c|}{2003} & \multicolumn{2}{|c|}{2017} \\
\hline & $\mathbf{r}$ & Sig. & $\mathbf{r}$ & Sig. & $\mathbf{r}$ & Sig. & $\mathbf{r}$ & Sig. & $\mathbf{r}$ & Sig. & $\mathbf{r}$ & Sig. \\
\hline AREA & 0.344 & 0.030 & 0.307 & 0.050 & -0.340 & 0.002 & -0.215 & 0.000 & 0.217 & 0.000 & 0.144 & 0.000 \\
\hline SHAPE & 0.429 & 0.006 & 0.351 & 0.026 & -0.492 & 0.001 & -0.399 & 0.011 & 0.064 & 0.000 & 0.563 & 0.000 \\
\hline LPI & 0.417 & 0.008 & 0.327 & 0.040 & -0.599 & 0.000 & -0.249 & 0.000 & 0.400 & 0.011 & 0.086 & 0.000 \\
\hline AI & 0.583 & 0.000 & 0.210 & 0.000 & -0.686 & 0.000 & -0.272 & 0.089 & 0.270 & 0.091 & 0.175 & 0.000 \\
\hline
\end{tabular}

AREA = Mean Patch area; SHAPE = Mean Shape Index; LPI = Largest Patch Index; AI =Aggregation Index.

Significant value is at the 0.05 with 2 tailed.

However, Green 2 and the mean LST $(r=0.563)$ showed a robust positive relationship with SHAPE_MN in 2017. LPI of Built up and Green 2 shows a positive correlation with the mean LST $(r=0.417$ and $r=0.400$ in 2003; $r=0.327$ and $r=0.086$ in 2017). All four metrics, namely, AREA_MN, SHAPE_MN, LPI, and AI of Built up, Green 1 and Green 2, were certified; possible influence can affect the mean LST (Table 4). The large patches of Green 1 can make a robust cooling environment than the small patches of Green 1 [55-58]. Our study also reveals that the large patches of Built up produce a significant heat effect, while the smaller patches of Built up make the relatively lower UHI effect.

\section{Discussion}

\subsection{Impacts of Urbanization}

The findings show that urbanization took place mainly towards east and west directions (Figure 2). It also spread toward the north direction. Some studies mention that Accra has experienced rapid urbanization [24,59]. The number of recorded inhabitants was 1.9 million in 1985 [60], and the population of the region had become 4.6 million in 2016 [61]. The annual population growth rate was $3.5 \%$ between 2000 and 2017, and the projected population will be doubled by 2040 [62]. This situation has had not only positive impacts on their inhabitants, socially and economically but also considerable adverse effects on the natural environs. The urbanization effect of Accra has been weakened by the existence of Green 1 and Green 2 (Figure 2). The different push and pull factors are influencing the urban growth pattern in Accra [62]. For example, push factors are the high rent price in the downtown of Accra and flood occurrences in the Accra core area. The government projects on the redevelopment plan are extending from the urban core area to the urban periphery $[23,63]$. There are a few pull factors. The availability of free lands to build houses is one of them [23,62]. The study results prove other impacts of rapid urban growth, including the UHI phenomenon.

\subsection{LST Pattern Along the Urban-Rural Gradient}

Based on the urban-rural gradient analysis, the zones near the city center did not show the highest mean LST in 2003 and 2017. According to that, the density of Built up and Green 1 was strongly correlated with each other, both in 2003 and 2017. The highest WI values showed closer to the city center along the urban-rural gradient. The neighborhood water bodies, other water resources, and humidity can result in the cooling environment around the city center. Therefore, the city center and surrounding environment did not have the highest mean LST value in the given study period (Figure 6). However, there are three peaks of the mean LST, which can be observed from $2 \mathrm{~km}$ to $7 \mathrm{~km}$, from $13 \mathrm{~km}$ to $18 \mathrm{~km}$, and from $22 \mathrm{~km}$ to $23 \mathrm{~km}$ from the city center. The population growth and the development of multicore urban structures from 2003 to 2017 accounted for enhancing the LST in these zones. The visual interpretation shows more fragmentation of the Built up area in the classified 2003 
map and less fragmentation of the Built up area in the 2017 map. However, the real situation indicates that the Built up area in 2003 was less fragmented and the Built up area in 2017 was more fragmented due to high rise buildings and the expansion of concentric urban centers away from the city center. These kinds of human activities enhanced the spatial formation of LST in the given zones.

The lowest mean LST can be observed from $20 \mathrm{~km}$ to $21 \mathrm{~km}$, with a contrast of $1.4^{\circ} \mathrm{C}$ in 2003 and $0.28^{\circ} \mathrm{C}$ in 2017. The formation of the mean LST along the urban-rural gradient of Accra shows typical characteristics of the UHI, with LST steadily declining along the urban-rural gradient with physical features [30]. Similar findings were reported by Estoque et al. (2017) [11] in the UHI study in three megacities of Southeast Asia. The Built up density was high around these zones, and the Green 1 density was very low. However, from $22 \mathrm{~km}$ to $23 \mathrm{~km}$, the peak area had a high density of Green 2. The Green 2 category is vital for Accra because it has a higher mean LST than Green 1 . Therefore, the temperature of Green 2 continuously influences the LST in the region. City planners of Accra should pay much attention to the existence of Green 2 areas in their urban design. As a result, GI of the TCT had the lowest value from $1 \mathrm{~km}$ to $17 \mathrm{~km}$, and high BI value in these zones accounted for increased LST in the area. The WI gradually fell along the urban-rural gradient.

The decreasing trend of the mean LST was evident from 7-8 km to 12-13 km (Figure 6) and "Densu Delta Protected Area", "Pambros Salt Basin", and "Achimota Forest Reserve" were positioned in corresponding zones (Figure 1d). These natural environments have plenty of vegetation, including subtropical trees, grassland, and bushland. This is a cause of the cooling effect near the city center. Another decreasing trend of the mean LST was prominent from $18 \mathrm{~km}$ to $21 \mathrm{~km}$ from the city center. "Weija Reservoir," and "Sakumo Lagoon Protected Area" were located in these areas (Figure 1d). The vast water reservoir and plenty of mangrove forests in the lagoon area have caused the cooling effect of the city. These results were similar to other studies that analyzed the influence of natural environs on the LST cooling $[18,64,65]$. Urban planners need to pay much attention to the central area of Accra to mitigate the UHI effect. The massive size of water areas and surrounding natural zones should be preserved. We identified that the LST value of Accra in 2003 and 2017 was dependent on not only LCCs, but also on different environmental factors such as significant air masses, dust, humidity, solar radiation, and air moisture when the Landsat thermal band imageries were investigated.

\subsection{Density of Land Lover Categories and TCT vs. LST at Multiresolution Grid-Based Analysis}

The multiresolution grid-based analysis explored that Built up density and Green 2 density were most associated with the raising of the LST (Figure 7). However, Green 1 was the most relevant cooling effect on the LST. Estoque et al. (2017) [11] found similar results using the data on an impervious surface and green space in three megacities in Southeast Asia (a suitable grid size was $210 \times 210$, and $240 \times 240$ for Bangkok, Jakarta, and Manila and all results were statistically significant at the $(\rho<0.001)$. Xiao et al. (2007) [47] made clear that the relationship between impervious surface and mean LST became stronger while grid size enlarged around $30 \mathrm{~m}$ to $960 \mathrm{~m}$. All of the correlations were significant $(\rho \leq 0.05)$.

Testimonies regarding the mean LST in each TCT analysis with multiresolution grids indicate that BI has improved the UHI of Accra (Figure 8). The BI of the TCT map shows that the higher BI had emitted of Built up category compared to the LUC maps in 2003 and 2017 (Figures 3 and 5). By contrast, the GI and WI have visible evidence of the cooling effect on the LST. The GI of the TCT map has the highest GI value in the northeast part of the study area. Compared to the LUC maps, these areas correspond to Green 1 of the regions (Figures 3 and 5). However, in comparison with the Green 2 category of LUC maps and the GI of TCT, we observe that Green 2 areas in the GI maps have a low degree effect (1-40) for cooling down the LST. Rasul et al. (2015) [66] focused on the urban cool island effect in Erbil, Iraqi Kurdistan, using TCT. They found a strong positive correlation with the mean LST and BI $(r=0.75)$ and the negative relationship with the mean LST and GI and WI $(r=-0.39$ and $r=-0.9)$ using Landsat 8 OLI/TRIS data. 
It is essential to mention that the correlation between all LCCs with the mean LST, and the correlation between TCT and the mean LST did not increase the equal quantity around the grid size of $210 \mathrm{~m} \times 210 \mathrm{~m}$ or $240 \mathrm{~m} \times 240 \mathrm{~m}$. The slope of the correlation was flat after passing the mentioned grid size (Figures 7 and 8). The $210 \mathrm{~m} \times 210 \mathrm{~m}$ and $240 \mathrm{~m} \times 240 \mathrm{~m}$ were proper grids of LCCs that affected land temperature. On the other hand, these grid sizes are the most suitable for forecasting methodological parameters and ecological features employing statistical relationships in land temperature and atmospheric temperature and LCCs, as well as spatial collocation. The results were similar to other studies: Myint et al. (2010) [50] have studied the UHI effect in Phoenix in the USA, and Hao Hou et al. (2020) [51] have discussed the cooling effect by using landscape composition and configuration in Hangzhou, China.

\subsection{Effect of Land Cover Features and Spatial Collocation vs. LST}

Our study indicates that the mean LST is statistically significant with the density of the Built up (positive correlation), Green 1 (negative correlation), and Green 2 (positive relationship) in both urban-rural gradient analysis and multiresolution grid-based analysis in 2003 and 2017 (Figures 6 and 7). These findings are relevant to Estoque et al. (2017) [11], Xiao et al. (2007) [47], and Myint et al. (2013) [46]. On the other hand, our findings of four spatial metrics show statistical significance with the mean LST both in 2003 and 2017. AREA_MN, SHAPE_MN, LPI, and AI with the mean LST had a positive relationship with Built up, negative correlation with Green 1, and positive relationship with Green 2, both in 2003 and 2017 (Table 4). Li et al. (2012) [56], Zhou et al. (2011) [67], Maimaitiyiming et al. (2014) [48], and Zhou et al. (2017) [68] explored that those spatial metrics of Built up and Green 1 were significantly correlated with the mean LST. Peng et al. (2016) [69] identified a relationship between the LST and the shape and fragmentation of natural land in Beijing. Asgarian et al. (2015) [70] revealed that a patch shape with highly aggregate edges produced more substantial mitigating of the LST effect in Isfahan, Iran. Masoudi et al. (2019) [71] examined the correlation between the LST pattern and green areas in four Asian cities, namely Kuala Lumpur, Hong Kong, Jakarta, and Singapore, using $240 \mathrm{~m}$, revealing that landscape configuration in Hong Kong and Kuala Lumpur had not affected the LST and the patches of the low fragmented green area were created in LST cooling in Singapore and Jakarta.

It is important to note that the rapid urbanization transforms natural environments into the Built up, which is retaining more solar radiation and releasing less solar radiation reflected [3]. According to that, LST influences the land temperature, but its surrounding air temperature and other environmental factors (wind/humidity) impact human health and thermal comfort. Vegetation and shadow help to reduce surface temperature. One solution to minimize the UHI is to grow plenty of trees and grass in the study area. Based on SHAPE_MN, we found that Green 2 could act to provide a lower surface temperature (Table 4). On the other hand, tree covers can create an urban cool island condition by evapotranspiration. In general, evapotranspiration by plants absorbs ambient heat and release water vapor to the atmosphere $[11,13]$.

Furthermore, urban vegetation cover serves to enhance the air quality of urban environs, which help reduce air pollution and mitigate the UHI effect of vital for the city dwellers. The public parks and recreational facilities are needed to minimize the UHI effect. In this context, city planners should play a significant role when designing the urban spatial structure by paying attention to the UHI phenomenon. The scattered and fragmented vegetation has a smaller cooling effect than the gathered vegetation pattern. Large clusters of vegetation increase the urban cool island effect. Therefore, it is crucial for city planners to attain the suitable spatial allocation of the urban landscape by designing large clusters of vegetation and scattering building environs.

\section{Conclusions}

In this study, we examined the spatial process of UHI's formation based on the LST in Accra by facilitating various geospatial techniques of TCT, urban-rural gradient, multiresolution grid-based 
analysis and spatial metrics in 2003 and 2017. We found that the distribution of UHI has dispersed and fragmented over time because of suburbanization. The Built up area increased from $30.51 \%$ to $51.09 \%$, and the Green 1 area decreased from $22.45 \%$ to $11.26 \%$, and the Green 2 area decreased from $46.71 \%$ to $32.49 \%$ from 2003 to 2017.

Daytime mean LST is high in Accra because it is located in a tropical sub-Sahara. We revealed that Built up and Green 2 caused the heating effect, and Green 1 and Water caused the cooling effect in the study area. The results indicated that the Accra's heat core was located 1-2 km far from the city center inside the central business district. The WI of TCT was gradually decreased along the urban-rural gradient, indicating considerable heat stress around the suburb. The density of Built up and the mean LST had a strong relationship when grid size became larger, and the density of Green 1 and mean LST had a more robust relationship when the grid size became smaller. It is concluded that $210 \mathrm{~m} \times$ $210 \mathrm{~m}$ and $240 \mathrm{~m} \times 240 \mathrm{~m}$ grid sizes are the most suitable for forecasting parameters and ecological features employing statistical relationships in land temperature and atmospheric temperature and LCCs in Accra. The urban cool island effect is dominant in Densu Delta Protected Area, Achimota Forest Reserve, Weija Reservoir, and Sakumo Lagoon Protected in Accra.

Urban planners and policymakers should pay attention to Green 2 because this category causes a higher mean LST. These findings give some insights for understanding spatial variations of the urban thermal environment and their spatial characteristics in a coastal city in a tropical sub-Saharan climate. Also, we found that multiresolution grid-based and landscape configuration analysis is useful to predict the impacts of the LUC pattern on the future UHI.

People are exposed to the increase in surface temperature in their life. Their daily socio-economic activities are significantly related to built up environs. In this case, it is better to control the UHI effect. Expanding and maintaining the large cluster of green covers is a critical time factor. We should consider the increase of dense vegetation areas, green roof, and scattered building environs to mitigate the UHI effect. Urban environments can have better-living conditions for city dwellers.

Author Contributions: Conceptualization, D.A.; methodology, D.A.; software, D.A.; validation, D.A., and Y.M.; formal analysis, D.A.; investigation, D.A.; resources, D.A.; data curation, D.A.; writing-original draft preparation, D.A.; writing-review and editing, Y.M.; visualization, Y.M.; supervision, Y.M.; project administration, Y.M.; funding acquisition, Y.M. All authors have read and agreed to the published version of the manuscript.

Funding: This study was partly supported by the JSPS grant 18H00763 (2018-20).

Acknowledgments: We would like to thank Kamusoko Courage for his valuable comments and suggestions.

Conflicts of Interest: The authors declare no conflict of interest. 


\section{Appendix A}

\# Spatial variation of land use/cover composition and impact on surface urban heat island in a tropical sub-Saharan city of Accra, Ghana \#
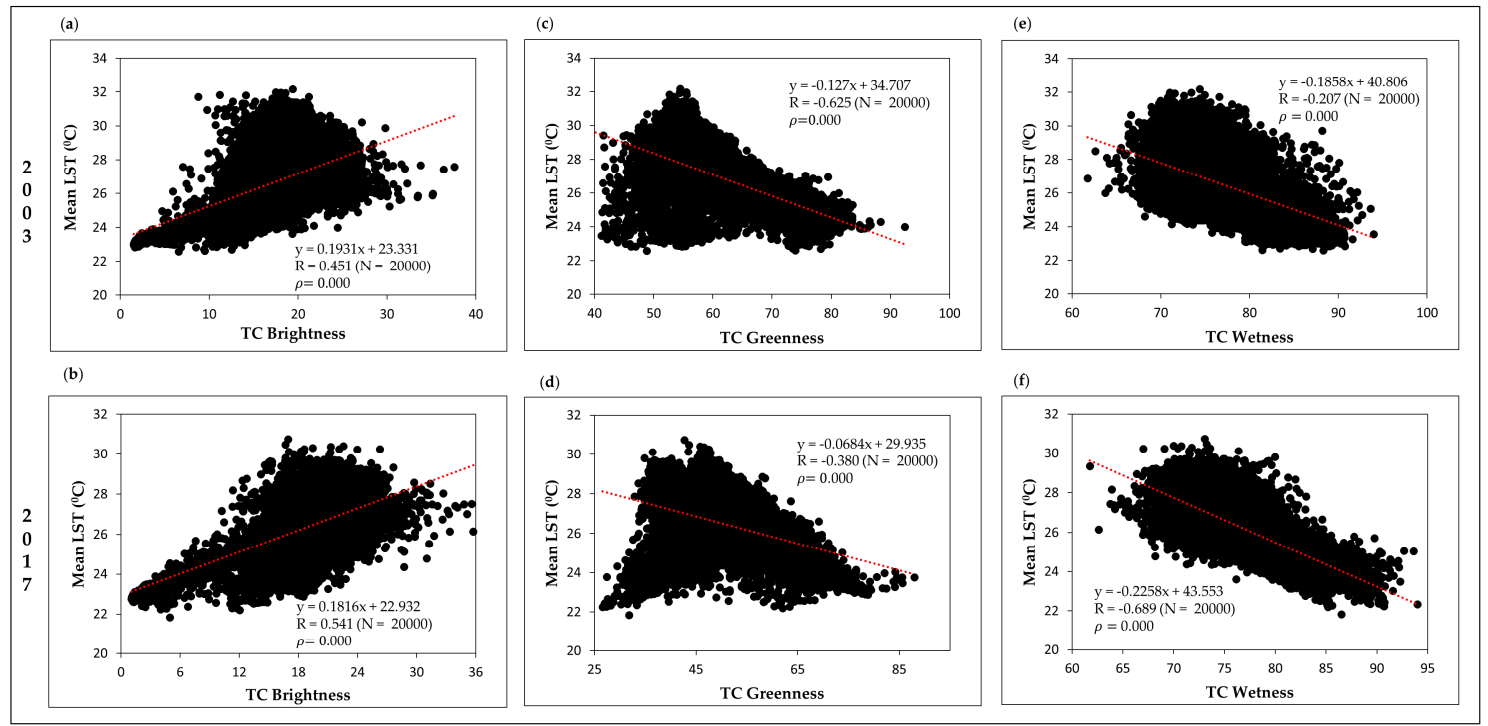

Figure A1. Pearson correlation results of BI, GI, WI with mean LST: (a) mean LST vs. BI in 2003; (b) mean LST vs. BI in 2017; (c) mean LST vs. GI in 2003; (d) mean LST vs. GI in 2017; (e) mean LST vs. WI in 2003; (f) mean LST vs. WI in 2017. Correlation is significant at the 0.01 level (2-tailed).

\section{References}

1. Estoque, R.C.; Murayama, Y. Quantifying landscape pattern and ecosystem service value changes in four rapidly urbanizing hill stations of Southeast Asia. Landsc. Ecol. 2016, 31, 1481-1507. [CrossRef]

2. Zhang, D.; Xu, J.; Zhang, Y.; Wang, J.; He, S.; Zhou, X.; Dan, Z.; Jiapeng, X.; Yizhu, Z.; Jing, W.; et al. Study on sustainable urbanization literature based on Web of Science, scopus, and China national knowledge infrastructure: A scientometric analysis in CiteSpace. J. Clean. Prod. 2020, 264, 121537. [CrossRef]

3. Michishita, R.; Jiang, Z.; Xu, B. Monitoring two decades of urbanization in the Poyang Lake area, China through spectral unmixing. Remote Sens. Environ. 2012, 117, 3-18. [CrossRef]

4. Weber, C.; Puissant, A. Urbanization pressure and modeling of urban growth: Example of the Tunis Metropolitan Area. Remote Sens. Environ. 2003, 86, 341-352. [CrossRef]

5. Franco, S.; Mandla, V.R.; Rao, K.R.M. Urbanization, energy consumption and emissions in the Indian context A review. Renew. Sustain. Energy Rev. 2017, 71, 898-907. [CrossRef]

6. Cao, H.; Chao, S.; Qiao, L.; Jiang, Y.; Zeng, X.; Fan, X. Urbanization-related changes in soil PAHs and potential health risks of emission sources in a township in Southern Jiangsu, China. Sci. Total Environ. 2017, 575, 692-700. [CrossRef]

7. Shahbaz, M.; Sbia, R.; Hamdi, H.; Ozturk, I. Economic growth, electricity consumption, urbanization and environmental degradation relationship in United Arab Emirates. Ecol. Indic. 2014, 45, 622-631. [CrossRef]

8. Al-Mulali, U.; Ozturk, I. The effect of energy consumption, urbanization, trade openness, industrial output, and the political stability on the environmental degradation in the MENA (Middle East and North African) region. Energy 2015, 84, 382-389. [CrossRef]

9. Wang, Y.; Du, H.; Xu, Y.; Lu, D.; Wang, X.; Guo, Z. Temporal and spatial variation relationship and influence factors on surface urban heat island and ozone pollution in the Yangtze River Delta, China. Sci. Total. Environ. 2018, 631-632, 921-933. [CrossRef]

10. Howard, L. The Climate of London; W. Phillips: London, UK, 1818; Volume 1. 
11. Estoque, R.C.; Murayama, Y.; Myint, S.W. Effects of landscape composition and pattern on land surface temperature: An urban heat island study in the megacities of Southeast Asia. Sci. Total Environ. 2017, 577, 349-359. [CrossRef]

12. Voogt, J.; Oke, T. Thermal remote sensing of urban climates. Remote Sens. Environ. 2003, 86, 370-384. [CrossRef]

13. USA Environmental Protection Agency. Reducing Urban Heat Islands: Green Roofs; Heat Island and Smog Reduction Act. Available online: https://www.epa.gov/heat-islands/heat-island-compendium (accessed on 23 September 2020).

14. Zhou, D.; Zhao, S.; Liu, S.; Zhang, L.; Zhu, C. Surface urban heat island in China's 32 major cities: Spatial patterns and drivers. Remote Sens. Environ. 2014, 152, 51-61. [CrossRef]

15. Alexander, C. Normalised difference spectral indices and urban land cover as indicators of land surface temperature (LST). Int. J. Appl. Earth Obs. Geoinf. 2020, 86, 102013. [CrossRef]

16. Estoque, R.C.; Ooba, M.; Seposo, X.T.; Togawa, T.; Hijioka, Y.; Takahashi, K.; Nakamura, S. Heat health risk assessment in Philippine cities using remotely sensed data and social-ecological indicators. Nat. Commun. 2020, 11, 1581. [CrossRef]

17. Yiran, G.; Kusimi, J.M.; Kufogbe, S. A synthesis of remote sensing and local knowledge approaches in land degradation assessment in the Bawku East District, Ghana. Int. J. Appl. Earth Obs. Geoinf. 2012, 14, 204-213. [CrossRef]

18. Estoque, R.C.; Murayama, Y. Monitoring surface urban heat island formation in a tropical mountain city using Landsat data (1987-2015). ISPRS J. Photogramm. Remote Sens. 2017, 133, 18-29. [CrossRef]

19. Min, M.; Zhao, H.; Miao, C. Spatio-temporal evolution analysis of the urban heat island: A case study of Zhengzhou City, China. Sustainability 2018, 10, 1992. [CrossRef]

20. Wu, Z.; Zhang, Y. Spatial variation of urban thermal environment and its relation to green space patterns: Implication to sustainable landscape planning. Sustainability 2018, 10, 2249. [CrossRef]

21. Zhang, X.; Estoque, R.C.; Murayama, Y. An urban heat island study in Nanchang City, China based on land surface temperature and social-ecological variables. Sustain. Cities Soc. 2017, 32, 557-568. [CrossRef]

22. Accra Metropolitan Assembly. Accra Resilience Strategy. Available online: https://ama.gov.gh/documentscentre.php (accessed on 23 September 2020).

23. Warner, L.; van de Logt, P. Climate change profile Mali. Clim. Serv. Cent. 2015, 1-17. Available online: https://ees.kuleuven.be/klimos/toolkit/documents/690_CC_mali.pdf (accessed on 29 July 2020).

24. Akubia, J.E.K.; Bruns, A. Unravelling the frontiers of urban growth: Spatio-temporal dynamics of land-use change and urban expansion in greater Accra metropolitan area, Ghana. Land 2019, 8, 131. [CrossRef]

25. Esri ArcGIS Online. Available online: https://www.esri.com/en-us/arcgis/products/arcgis-online/overview (accessed on 23 September 2020).

26. EarthExplorer. Available online: https://earthexplorer.usgs.gov/ (accessed on 29 July 2020).

27. DIVA-GIS. Available online: https://www.diva-gis.org/ (accessed on 29 July 2020).

28. Landsat Missions. Available online: https://www.usgs.gov/land-resources/nli/landsat (accessed on 29 July 2020).

29. Adeyeri, O.; Akinsanola, A.; Ishola, K. Investigating surface urban heat island characteristics over Abuja, Nigeria: Relationship between land surface temperature and multiple vegetation indices. Remote Sens. Appl. Soc. Environ. 2017, 7, 57-68. [CrossRef]

30. Weng, Q.; Lu, D.; Schubring, J. Estimation of land surface temperature-vegetation abundance relationship for urban heat island studies. Remote Sens. Environ. 2004, 89, 467-483. [CrossRef]

31. Li, W.; Du, Z.; Ling, F.; Zhou, D.; Wang, H.; Gui, Y.; Sun, B.Y.; Zhang, X. A comparison of land surface water mapping using the normalized difference water index from TM, ETM+ and ALI. Remote Sens. 2013, 5, 5530-5549. [CrossRef]

32. NASA. Landsat 7 Handbook. Available online: https://www.usgs.gov/core-science-systems/nli/landsat/ landsat-7-data-users-handbook (accessed on 23 September 2020).

33. U.S. Geological Survey. Landsat 8 Data Users Handbook. NASA. Available online: https://www.usgs.gov/ core-science-systems/nli/landsat/landsat-8-data-users-handbook (accessed on 23 September 2020).

34. Sobrino, J.A.; Jiménez-Muñoz, J.C.; Paolini, L. Land surface temperature retrieval from LANDSAT TM 5. Remote Sens. Environ. 2004, 90, 434-440. [CrossRef] 
35. Ayanlade, A.; Howard, M.T. Land surface temperature and heat fluxes over three cities in Niger Delta. J. Afr. Earth Sci. 2019, 151, 54-66. [CrossRef]

36. R: The R Project for Statistical Computing. Available online: https://www.r-project.org/ (accessed on 30 July 2020).

37. Kamusoko, C.; Aniya, M. Hybrid classification of Landsat data and GIS for land use/cover change analysis of the Bindura district, Zimbabwe. Int. J. Remote Sens. 2008, 30, 97-115. [CrossRef]

38. Erkan, U.; Gokrem, L. A new method based on pixel density in salt and pepper noise removal. Turk. J. Electr. Eng. Comput. Sci. 2018, 26, 162-171. [CrossRef]

39. Thapa, R.B.; Murayama, Y. Image classification techniques in mapping urban landscape: A case study of Tsukuba city using AVNIR-2 sensor data. Tsukuba Geoenviron. Sci. 2007, 3, 3-10.

40. Kauth, R.J.; Thomas, G.S. The Tasselled Cap_A Graphic Description of the Spectral-Temporal Development of Agricultural Crops as Seen by LANDSAT. 1976. Available online: https://docs.lib.purdue.edu/cgi/viewcontent. cgi?referer=https://www.google.com.hk/\&httpsredir=1\&article=1160\&context=lars_symp (accessed on 30 July 2020).

41. Crist, E.P.; Cicone, R.C. A physically-based transformation of thematic mapper data-The TM tasseled cap. IEEE Trans. Geosci. Remote Sens. 1984, 22, 256-263. [CrossRef]

42. Liu, Q.; Liu, G.; Huang, C.; Xie, C. Comparison of tasselled cap transformations based on the selective bands of Landsat 8 OLI TOA reflectance images. Int. J. Remote Sens. 2015, 36, 417-441. [CrossRef]

43. Weng, Q. A remote sensing? GIS evaluation of urban expansion and its impact on surface temperature in the Zhujiang Delta, China. Int. J. Remote Sens. 2001, 22, 1999-2014. [CrossRef]

44. Weng, Q.; Liu, H.; Lu, D. Assessing the effects of land use and land cover patterns on thermal conditions using landscape metrics in city of Indianapolis, United States. Urban Ecosyst. 2007, 10, 203-219. [CrossRef]

45. Wang, C.; Myint, S.W.; Wang, Z.H.; Song, J. Spatio-temporal modeling of the urban heat island in the Phoenix metropolitan area: Land use change implications. Remote Sens. 2016, 8, 185. [CrossRef]

46. Myint, S.W.; Wentz, E.A.; Brazel, A.J.; Quattrochi, D.A. The impact of distinct anthropogenic and vegetation features on urban warming. Landsc. Ecol. 2013, 28, 959-978. [CrossRef]

47. Xiao, R.B.; Ouyang, Z.Y.; Zheng, H.; Li, W.F.; Schienke, E.W.; Wang, X.K. Spatial pattern of impervious surfaces and their impacts on land surface temperature in Beijing, China. J. Environ. Sci. 2007, 19, 250-256. [CrossRef]

48. Maimaitiyiming, M.; Ghulam, A.; Tiyip, T.; Pla, F.; Latorre-Carmona, P.; Halik, Ü.; Sawut, M.; Caetano, M. Effects of green space spatial pattern on land surface temperature: Implications for sustainable urban planning and climate change adaptation. ISPRS J. Photogramm. Remote Sens. 2014, 89, 59-66. [CrossRef]

49. Weng, Q. Thermal infrared remote sensing for urban climate and environmental studies: Methods, applications, and trends. ISPRS J. Photogramm. Remote Sens. 2009, 64, 335-344. [CrossRef]

50. Myint, S.W.; Brazel, A.; Okin, G.S.; Buyantuyev, A. Combined effects of impervious surface and vegetation cover on air temperature variations in a rapidly expanding desert city. GISci. Remote Sens. 2010, 47, 301-320. [CrossRef]

51. Hou, H.; Estoque, R.C. Detecting cooling effect of landscape from composition and configuration: An urban heat island study on Hangzhou. Urban For. Urban Green. 2020, 53, 126719. [CrossRef]

52. Li, X.; Kamarianakis, Y.; Ouyang, Y.; Turner, B.L., II; Brazel, A. On the association between land system architecture and land surface temperatures: Evidence from a Desert Metropolis-Phoenix, Arizona, U.S.A. Landsc. Urban Plan. 2017, 163, 107-120. [CrossRef]

53. Lu, L.; Weng, Q.; Xiao, D.; Guo, H.; Li, Q.; Hui, W. Spatiotemporal variation of surface urban heat islands in relation to land cover composition and configuration: A multi-scale case study of Xi'an, China. Remote Sens. 2020, 12, 2713. [CrossRef]

54. Mcgarigal Fragstats. Fragstats. Available online: http://www.umass.edu/landeco/research/fragstats/fragstats. html (accessed on 23 September 2020).

55. Zhang, X.; Zhong, T.; Feng, X.; Wang, K. Estimation of the relationship between vegetation patches and urban land surface temperature with remote sensing. Int. J. Remote Sens. 2009, 30, 2105-2118. [CrossRef]

56. Li, X.; Zhou, W.; Ouyang, Z.; Xu, W.; Zheng, H. Spatial pattern of greenspace affects land surface temperature: Evidence from the heavily urbanized Beijing metropolitan area, China. Landsc. Ecol. 2012, 27, 887-898. [CrossRef] 
57. Cao, X.; Onishi, A.; Chen, J.; Imura, H. Quantifying the cool island intensity of urban parks using ASTER and IKONOS data. Landsc. Urban Plan. 2010, 96, 224-231. [CrossRef]

58. Yokohari, M.; Brown, R.D.; Kato, Y.; Moriyama, H. Effects of paddy fields on summertime air and surface temperatures in urban fringe areas of Tokyo, Japan. Landsc. Urban Plan. 1997, 38, 1-11. [CrossRef]

59. Addae, B.; Oppelt, N. Land-use/land-cover change analysis and urban growth modelling in the greater accra metropolitan area (GAMA), Ghana. Urban Sci. 2019, 3, 26. [CrossRef]

60. Farvacque-vitkovic, C.; Eghoff, C. Development of the Cities of Ghana: Challenges, Priorities, and Tools; Africa Region Working Paper Series, World Bank Group. 2008. Available online: http://documents1.worldbank. org/curated/en/318351468256521007/pdf/448710NWP0Box31UBLIC10AFRWP0no10110.pdf (accessed on 23 September 2020).

61. 2010 Population and Housing Census Final Results Ghana Statistical Service; Ghana Statistical Service: Accra, Ghana, 2012.

62. Enhancing Urban Resilience in the Greater Accra Metropolitan Area. Available online: https://elibrary. worldbank.org/doi/abs/10.1596/27516 (accessed on 23 September 2020).

63. Cities Alliance. Future Proofing Cities Metropolitan Cities in Ghana; Arup: London, UK, 2016.

64. Gage, E.A.; Cooper, D.J. Urban forest structure and land cover composition effects on land surface temperature in a semi-arid suburban area. Urban For. Urban Green. 2017, 28, 28-35. [CrossRef]

65. Yang, J.; Sun, J.; Ge, Q.; Li, X. Assessing the impacts of urbanization-associated green space on urban land surface temperature: A case study of Dalian, China. Urban For. Urban Green. 2017, 22, 1-10. [CrossRef]

66. Rasul, A.; Balzter, H.; Smith, C. Spatial variation of the daytime surface urban cool island during the dry season in Erbil, Iraqi Kurdistan, from Landsat 8. Urban Clim. 2015, 14, 176-186. [CrossRef]

67. Zhou, W.; Huang, G.; Cadenasso, M.L. Does spatial configuration matter? Understanding the effects of land cover pattern on land surface temperature in urban landscapes. Landsc. Urban Plan. 2011, 102, 54-63. [CrossRef]

68. Zhou, W.; Wang, J.; Cadenasso, M.L. Effects of the spatial configuration of trees on urban heat mitigation: A comparative study. Remote Sens. Environ. 2017, 195, 1-12. [CrossRef]

69. Peng, J.; Xie, P.; Yanxu, L.; Ma, J. Urban thermal environment dynamics and associated landscape pattern factors: A case study in the Beijing metropolitan region. Remote Sens. Environ. 2016, 173, 145-155. [CrossRef]

70. Asgarian, A.; Amiri, B.J.; Sakieh, Y. Assessing the effect of green cover spatial patterns on urban land surface temperature using landscape metrics approach. Urban Ecosyst. 2014, 18, 209-222. [CrossRef]

71. Masoudi, M.; Tan, P.Y.; Liew, S.C. Multi-city comparison of the relationships between spatial pattern and cooling effect of urban green spaces in four major Asian cities. Ecol. Indic. 2019, 98, 200-213. [CrossRef] 